China Perspectives

60 | july - august 2005

Varia

\title{
Unequal Primary Education Opportunities in Rural and Urban China
}

Teng Margaret Fu

\section{Q OpenEdition}

1 Journals

Édition électronique

URL : http://journals.openedition.org/chinaperspectives/500

DOI : 10.4000/chinaperspectives.500

ISSN : 1996-4617

Éditeur

Centre d'étude français sur la Chine contemporaine

Édition imprimée

Date de publication : 1 août 2005

ISSN : 2070-3449

Référence électronique

Teng Margaret Fu, « Unequal Primary Education Opportunities in Rural and Urban China », China Perspectives [En ligne], 60 | july - august 2005, mis en ligne le 01 juin 2008, consulté le 10 décembre 2020. URL : http://journals.openedition.org/chinaperspectives/500 ; DOI : https://doi.org/10.4000/ chinaperspectives.500

Ce document a été généré automatiquement le 10 décembre 2020.

(C) All rights reserved 


\title{
Unequal Primary Education Opportunities in Rural and Urban China
}

\author{
Teng Margaret Fu
}

1 Place matters in China. The income gap between rural and urban residents is widening. Average urban incomes are more than four times higher than average rural incomes, when considering all the subsidies that urban residents receive for housing, medicine and education, and adjusted for the higher tax burden of rural residents ${ }^{2}$. This article examines one such subsidy that has contributed to the disparity between urban and rural life in China, namely government-supported primary education in urban areas as opposed to family-supported primary education in rural areas. While the state has been the primary financial supporter for urban children, rural children have been, for the most part, left to the sponsorship of their families and local collectivities (villages and townships). Considering the fact that education is often directly linked to a better standard of living, and considering increasing rural discontent and unrest due to heavy peasant burdens and worsening living conditions, how to level the playing field, clarify the relationship among different levels of government in the provision of primary education for rural residents, and improve education opportunities for rural children remain the main tasks for the Chinese government.

2 Primary education in rural China has been marginalised for a considerable period of time. It is compromised, firstly, by the societal emphasis on economic development that puts more immediate and measurable economic growth ahead of a more long-term and less visible improvement in educational development. Secondly, it is weakened by the fact that urban education enjoys more attention and resource input from the central government. Due to the lack of public educational funding in rural areas, children from peasant families are usually forced to drop out of schools at the junior high, or even primary level, thus losing the opportunity to take the national College Entrance Examination to further their studies at institutes of higher learning. The ratio of the urban primary school enrolment rate versus that of rural enrolment rate was 
four to three in 2002, which meant that 1.1 million children in rural areas were unable to attend primary school ${ }^{3}$. From an early age, these children are in a disadvantageous position. The unequal distribution of opportunities to pursue higher education is also shown by statistics that indicate that urban youth is more than three times more likely to be admitted to college and university than rural youth. According to Hong Wei from the Peking Academy of Education and Science, the proportion of new students from rural areas admitted by Qinghua University dropped from $20.8 \%$ in 1998 to $17.6 \%$ in 2000; the proportion of rural students admitted by Peking Normal University dropped from $30.9 \%$ in 1998 to $22.3 \%$ in 2002 . Moreover, in 1999, urban students dominated military academies, colleges and universities affiliated with state ministries, and art academies, with a proportion of $90 \%$ to $99 \%^{4}$.

3 This article begins with a review of the two-track system that has contributed to the current disparity between urban and rural areas. As primary education is believed to be local, the geographical location of a child's registered permanent residence predetermines where the child attends primary and junior high school. Differences have thus emerged in terms of the funding and purpose of education. The latter part of the essay focuses on the dominant task of primary education at present-the universalisation of compulsory education-to demonstrate the urgency and existing difficulties that the government faces in the provision of rural primary education. The prospect of a successful delivery of rural primary education lies in the further clarification of the financial relationship among different levels of the government, the diversification of sources of funding and the serious integration of primary education with economic growth in the goal of a more sustainable development.

The two-track system

The history of the two-track system can be traced back before the founding of the PRC in 1949. Due to limited educational resources, village schools were supported by local communities, and urban schools were supported by the Nationalist Government by 19495. After 1949, the new PRC government accepted the same model. In 1951, the State Council issued the "Decision on the Reform of the Education System", acknowledging the existence of the two tracks of education. Two years later, the State Council issued a "Directive Concerning the Reorganisation and Improving of Primary Education". The Directive stressed the importance of developing education in cities, and industrial and mining areas to meet the demands of industrialisation, and reaffirmed "the principle of voluntariness and need should be the basis upon which to promote the operation of primary schools by the people". This principle of "selective development" in the education policy meant that rural people had to take up the responsibility of educating their children. Educational expenditures had to be raised and maintained by the rural masses, while the city residents were subsidised for the same needs and desires.

Moreover, the system was further established with Liu Shaoqi's theory of "two kinds of labour and two kinds of education system" in 1962. While affirming the equal importance of the two tracks of educational provision, Liu explained the rationale behind the government's choice to separate the two kinds of educational provision. Again, the given reason referred to the lack of sufficient resources. For a country with limited capital to quickly produce qualified experts for modernisation, it was necessary to concentrate on a number of key schools and urban schools to train a selected group of talented young people to serve the economic development as experts. The economic situation of the country had to be sufficiently improved before it could be aligned to 
fuel the development of enhanced educational facilities on a large scale. Until then, students in the rural track had to rely on themselves and take whatever form of education their "objective local conditions" allowed. These people were to be "a generation of literate successors with correct socialist consciousness"'. Urban youth was chosen to be the future elite, artificially.

Indeed, local variations were taken into account in the continuation of the traditional two-track system. And it did begin on a voluntary basis. The peasants were the ones who first rejected attempts to institutionalise a more regularised schooling system for all children, because the content and timing of a standardised education were found to be unsuitable for the local needs of agricultural labour. The peasants under their village leaders thus initiated people-run schools (minjian xuexiao) with flexible arrangements adapted to the rhythm of agricultural life ${ }^{8}$.

7 However, the unintended consequence of the pursuit of this policy has been a situation of unequal education opportunities. Rural children were "planned" to be localised while urban children were granted more opportunities to continue their education in colleges and universities that further promised higher-status job positions. As urban schools were supported by the government, while rural schools were mainly provided for by local communities, opportunities to obtain education could be significantly constrained, depending on local conditions.

8 It is interesting to note that during the utopian-driven era of Cultural Revolution (1966-1976), the inequalities between urban and rural schools were eliminated. Educational opportunity was popularised as a human right, except for the first two years when education at all levels was suspended. In 1968, when schools were reopened, primary education became a single-track five-year system in which rural and urban children received the same education'. Selection for secondary and higher education was no longer based on academic achievements, but work experience and political activism, favouring workers and peasants instead of the intelligentsia. Good class origins of workers and peasants overshadowed any other criteria for high-status job positions. The ideal of absolute egalitarian and communitarian living left learning mainly based on practices in productive labour and class struggles ${ }^{10}$.

With the focus on economic development and the pursuit of economic decentralisation to achieve the goal, the reform era has witnessed a demolition to the local levels of the responsibility for the provision of rural primary education. The two-track system has gradually returned. The underlying mentality behind this is similar to that of the period from 1949 to 1966: the state has to concentrate limited resources on a few "key point" schools to quickly train experts for the modernisation endeavour. The two-track system is again characterised by state-subsidised urban schools and people-run rural schools, and further distinguished by "key" and "non-key" schools within each system. The circular of the "Draft Plan for a Ten Year Full-Time Teaching System" promulgated in early 1978 acknowledged openly that the task of schools in the countryside was not to supply higher institutions with high standard students but to train competent workers ${ }^{11}$.

10 Consequently, the financial support for the provision of primary education shifted towards localities. The central government and provincial governments do occasionally provide finance for education at lower levels. But these grants are often only for specific projects. They are not annually recurring, or even renewable budgetary operational funds. In 1985, the Central Committee of the CCP issued the "Decision on 
the Reform of the Education Structure". Principals of primary schools, together with those at other levels of education, were given so-called administrators' autonomy. Rural areas aside, even in urban areas, funding provided by the government to cover financial needs decreased. The growing financial constraints were attributed to the interministerial competition for scarce resources and the misuse of funds earmarked for education for the more tangible economic development.

The arduous task of universalising compulsory education

11 Currently, the dominant task of primary education is to universalise compulsory education, especially in rural areas ${ }^{12}$. Despite "The Compulsory Education Law" being passed in 1986 and "The Rule for the Implementation of the Compulsory Education Law of the People's Republic of China" in 1992, primary schooling is still not universal. According to Feng Wang, compulsory rural education stood at $76 \%$ in $2002^{13}$. In many rural areas, the reported high enrolment rate disguised an equally high dropout rate. It has also been difficult to track the true dropout rate, as the authenticity of some statistics provided is questionable ${ }^{14}$.

12 The difficulty in providing quality rural primary education lies in the unsettled financial relationship between the centre and the localities, resulting in a shortage of educational funding and resources in rural areas. Without sufficient funding, school facilities cannot be maintained, and school teachers cannot be provided.

The lack of village teachers is common in rural China. When their basic salaries are not even guaranteed in some poor rural areas, it is not surprising that teachers leave for urban areas where they are provided with not only salaries, but also additional housing, pensions and medical subsidies. In some areas, such as Gong County, Yunnan province, there are over 60 village schools with only one or two teachers who are responsible for teaching all subjects at all grade levels ${ }^{15}$. As Fanping Meng notes, teachers lack incentives to remain in poor and remote villages that cannot even guarantee their basic living expenses. These instructors are ultimately compelled to move to urban schools, even though they might have to teach less and handle more administrative matters. In an urban junior high school in Henan province, there are ten former teachers from nearby rural areas doing administrative work ${ }^{16}$. There are innumerable cases like these where rural areas have lost teaching personnel to more advanced and better-regarded urban areas.

14 The unclear financial relationship in the provision of primary education in rural China also results in the lack of funding for the maintenance of school facilities. Dangerously dilapidated school buildings cannot be renovated, and much needed furniture and other equipment cannot be purchased. To achieve the compulsory education goals set by the central government at different periods of time, some school principals have been forced to borrow money from local industries. Cases that involve rural school principals who are unable to repay such debts have already drawn great attention from scholars in study of China's education laws and society at large ${ }^{17}$.

15 The questions are thus: who is responsible for the provision of rural primary education? What are the sources of funding for universalising compulsory education? It is obvious that peasants cannot afford to pay the expenses of education wholly by themselves. When urban residents are subsidised for their children's primary education, where can rural residents go for support? provision of such basic public goods as primary education. Experiences associated with 
the rise of Japan and South Korea after World War II offer thought-provoking examples. Both governments have put great emphasis on educational investment, and the funding for the universalisation of compulsory education in particular ${ }^{18}$. Funding for compulsory education as a proportion of public educational expenditure has been consistently above 50\% since 1952 in Japan. And 75\% of the educational input was in primary compulsory education in the 1950s in South Korea. By contrast, China has not yet put enough financial input into public education in general. Based on the standard that public educational expenditure should take up $4 \%$ of the gross national product (GNP) in developing countries, scholars calculated the deficit that the Chinese government accumulated during the 1985-2002 period, the gap between what the government did provide and what it should provide, to be over a trillion yuan ${ }^{19}$. In 1985 , the share of educational expenditure of China's GNP was $2.9 \%$, ranking it 120 th in the world. It was still less than $3 \%$ in 1993 , compared to the $6 \%$ average for all countries, and about $5 \%$ for Asian countries ${ }^{20}$. Article 43 of the "China Education Reform and Development Outline" issued in February 1993 stipulated that national fiscal educational expenditure as a proportion of the GNP was to be increased to $4 \%$ by the end of the century. Yet, the 2000 percentage not only did not reach the goal, it was also lower than the 1986 and 1990 percentage. The government since postponed this goal further until 2005 in the "National Education Tenth Five Plan and 2015 Development Plan" issued in $2001^{21}$.

Indeed, the government should not shed the responsibility of providing equal education opportunities for rural residents in the name of limited resources. After all, urban schools have been allocated more resources and funding than rural schools throughout the history of the PRC. Bin Liu, member of the Education, Science, Culture and Public Health Committee of the National People's Congress, argues that governments at different levels should co-ordinate and allocate specific funding for the task of universalising compulsory education. It is unconscionable that school principals should alone shoulder the debt-repayment responsibilities. Qiyi Tian, the Education Bureau Chief of Shangqiu, Henan province, also believes that government should assume a larger role in raising funds to repay the debts ${ }^{22}$.

18 Then a more practical and immediate question becomes which level of the government should be mainly charged with the task.

By 2001, township-level governments were mainly responsible for the provision of local primary education. However, without sufficient financial input from the centre or higher-level governments, township governments largely resorted to the peasants for funding their children's primary education through the charges of tuition fees and "educational fee additional". Although the "educational fee additional" was supposed to be a one-off fee charged for the purpose of local primary education, peasants were burdened with different kinds of fees in the name of educational expenses. In some cases, the desperate need for funding was the reason for additional charges. Yet, with the focus on economic development, it was not rare to see educational funds used as emergency funds and allocated for other uses, such as setting up township and village enterprises. There were also documented occasions when educational funds were misused by corrupt officials on new administrative buildings, cars and banquets.

Several attempts have been made by the central government to reduce such types of peasant burdens, and to clarify the financial relationship between the centre and localities. To better manage educational funds, the State Council issued the "Decision 
on the Reform and Development of Primary Education" in 2001, setting county-level government as the new main engine for the provision of rural primary education. The "Directive Concerning the Improvement of the Organisational Structure of Rural Compulsory Education" issued by the State Council in 2002 further emphasised that the county governments should assume the primary role in providing and improving the compulsory education in rural China, with other levels of governments playing a facilitating and supporting role. The central government was mainly charged with drafting regulations, policies and guidelines for all levels of governments, and focusing fiscal transfers (caizheng zhuanyi zhifu) onto the designated poorest areas in middle and west China. Provincial governments were to play a key role in co-ordinating resources for rural primary educational development. With increases in local financial strength, as the economy develops, provincial governments were to increase their capabilities in fiscal transfers too. Village and township governments were mainly in charge of organising and monitoring local educational development ${ }^{23}$.

21 Furthermore, the tax-for-fees reforms in 2002-2003 eliminated all but two of the previous local fees and taxes (agricultural tax and a surcharge on the new agricultural tax) collected by village and township officials ${ }^{24}$. In particular, education offices at the township level were to be abolished, salaries for school teachers were to be distributed by the county governments, and rural schools were also to be managed by the counties $^{25}$. To further alleviate peasant burdens and avoid over-collection and misuse of educational funds, a "one-fee system" began to be implemented nationwide in 2004. Provincial government is to assess and determine the cost of educational fees, and students are to be charged once only the cost of their education. The collection of additional fees is prohibited ${ }^{26}$.

In addition to these government policy initiatives, additional financial support is expected from different social forces. As growing media attention exposes the poor conditions at rural schools, concerned individuals and non-governmental organisations, both domestically and internationally, have been playing an increasingly active role in offering additional finances and resources to provide rural children with more education opportunities. The Yunnan Minority Basic Education Project run by Save the Children and Yunnan Provincial Education Commission, for example, have introduced funding and training for teachers in rural schools in mountainous areas in Yunnan province ${ }^{27}$. The proportion of private funds (donated by individuals, rural enterprises, NGOs, etc.), outside of governmental funds for education, of the total educational input rose from $24.8 \%$ in 1995 to $33.4 \%$ in 2000 . A trend of increasingly diverse sources of educational input is emerging in China ${ }^{28}$.

In conclusion, China's two-track system has resulted in an uneven and unequal distribution of educational opportunities. The development of urban primary education and the training of "urban elites" should not be at the expense of provision of rural primary education. China's limited resources and inadequate total government spending on education cannot justify the current inequality in educational opportunities for rural and urban residents.

Recent government policy measures have been targeted at a clearer relationship among different levels of government in the provision of rural compulsory education. As counties have reasserted more control over the collection and expenditure of educational funds and resources, the tracking of cash-flows is expected to become easier and more accurate. Village and township cadre corruption is expected to be 
more difficult to tackle. The diversification of sources of educational funding, including the encouragement of support from society, from the government sphere, promises better opportunities for education for rural children. However, the basic problem of inadequate educational funding for rural schools remains unresolved at present, as it takes time to evaluate these new policy initiatives, and absorb the increasing support from central and provincial fiscal transfers and private donations from social forces. The major challenge continues to be how to integrate rural primary education with rural poverty alleviation, development and stability, and achieve the goal of sustainable development in China.

\section{NOTES}

1. I thank Geoff Lordi for his full support.

2. Deborah Davis, “China's 'Software Advantages”, Woodrow Wilson International Center for Scholars Asia Program Special Report: China’s Economy: Will the Bubble Burst?, June 2003, p. 18.

3. "Zhongguo nongcun jiaoyu shengshiweiyan," (Warnings to China's Rural Education), China Youth Daily, October 26th 2004, http://news.qq.com/a/20041026/000017.htm

4. Ibid. Military, art academies and colleges and universities affiliated with state ministries are considered more prestigious among the same level of higher education institutions, thus they are more favourable to applicants, and usually require higher admission scores.

5. Billie L.C. Lo, "Primary Education: A Two-Track System for Dual Tasks", in Ruth Hayhoe (ed.), Contemporary Chinese Education, London, Croom Helm, 1984, p. 47.

6. Ibid.

7. Ibid., p. 48.

8. Ruth Hayhoe, "The Evolution of Modern Chinese Educational Institutions", in Ruth Hayhoe (ed.), Contemporary Chinese Education, op. cit., p. 33.

9. Billies L. C. Lo, "Primary Education: A Two-Track System for Dual Tasks", op. cit., p. 48.

10. Ibid., p. 44.

11. Ibid., p. 51.

12. Compulsory education is stipulated to include six-year primary schooling and three-year junior high schooling.

13. "Zhongguo nongcun jiaoyu shengshiweiyan", op. cit.

14. Ibid.

15. Correspondence with China River Networks regarding its Green Support Project on file with the author, October 2004.

16. Meng Fanping, "Nongcun jiaoshi yu jiaoyu de wenti he duice," (Problems and Recommendations Regarding Rural Teachers and Rural Education) Zhongguo jiaoyu bao (China Education Daily), March 19th 2004, http://www.jyb.com.cn/gb/2004/03/19/zy/ 5-shzk/2.htm. 
17. Zhou Fei, “'Pujiu' qianzhai, zhengfu 'maidan"' (Debts incurred by the "Universalization of Compulsory Education" should be paid by the Government), Zhongguo jiaoyu bao (China Education Daily), May 12th 2002, http://www.jyb.com.cn/ $\mathrm{gb} / \mathrm{jybzt} / 2002 \mathrm{zt} / \mathrm{zxxy} / 20 . \mathrm{htm}$.

18. Zhao Minxia, "Jichu jiaoyu junheng fazhan bijiao yanjiu" (A Comparative Study on the Even Development of Primary Education), Xiandai jiaoyu bao (Modern Education Newspaper), http://www.pep.com.cn/200406/ca522572.htm.

19. Project Group of the Academy of Education Policy and Law of Beijing Normal University, "Jiaoyu touru, qunian xuezhe shuole xie shenme" (Education Input, What Scholars Said Last Year), Zhongguo jiaoyu bao (China Education Daily), April 23rd 2005, http://www.jyb.com.cn/gb/2005/04/23/zy/jykx/1.htm.

20. Xue Lanrong, "Compulsory Education and Modernization-A Chinese Dilemma", in $\mathrm{Hu}$ Jixuan, Hong Zhaohui and Eleni Stavrou (eds.), In Search of A Chinese Road Towards Modernization: Economic and Educational Issues in China's Reform Process, Lewiston, NY, The Edwin Mellen Press, 1996, p. 259.

21. Project Group of the Academy of Education Policy and Law..., op. cit.

22. Zhou Fei, op. cit.

23. Xinhua News Agency Co-op, "Yi xian weizhu, luoshi zeren" (Clarify the Responsibilities based on Counties), Zhongguo jiaoyu bao (China Education Daily), May 17th 2002, http://www.jyb.com.cn/gb/2002/05/17/zy/jryw/2.htm.

24. Jean C. Oi, "State Responses to Rural Discontent in China: Tax-for-Fee Reform and Increased Party Control", Woodrow Wilson International Center for Scholars Asia Program Special Report: Crisis in the Hinterland: Rural Discontent in China, March 2003, p. 5.

25. Xinhua News Agency Co-op, "Yi xian weizhu, luoshi zeren", op. cit.

26. " 27 ge shengfen chutai bing zhixing yiwu jiaoyu 'yifeizhi' shishi fangan" (Twentyseven provinces to be implementing the "One-Fee System" on Compulsory Education), Netease News, September 29th 2004, http://news.163.com/ 2004w09/12690/2004w09_1096447690969.html.

27. Save the Children, Yunnan Minority Basic Education Project, October 31st 2004, http://www.savethechildren.org.uk/scuk/jsp/resources/details.jsp? id=1985\&group=resources\&section=casestudy\&subsection=details\&pagelang=en. 28. Project Group of the Academy of Education Policy and Law..., op. cit.

\section{RÉSUMÉS}

This article examines the unequal provision of primary education in rural and urban China. It first looks at the development of the "two-track" system and shows how educational opportunities have always been unevenly distributed in contemporary China. It then focuses on the dominant task of primary education-the universalisation of compulsory education-to underscore the profound difficulties that the Chinese government faces particularly in the provision of primary education in rural areas. The article concludes that the prospect of a successful delivery of primary education in the countryside lies in the further clarification of the financial relationship among different levels of the government, the diversification of sources of 
educational funding, and the integration of primary education with economic growth as the goal of sustainable development ${ }^{1}$. 